\title{
IMPLEMENTASI METODE SNOWBALL THROWING UNTUK MENINGKATKAN MINAT DAN AKTIVITAS BELAJAR EKONOMI.
}

\author{
Fitri Nurlaili ${ }^{1)}$, Dewi Sulastri ${ }^{2)}$ \\ Universitas Banten Jaya \\ Serang,Indonesia \\ fitrinurlaili@unbaja.ac.id ${ }^{\mathbf{1})}$, dewisulastri@unbaja.ac.id ${ }^{2)}$
}

\begin{abstract}
This research was a classroom action research that aim to increase the interest and learning activities of economic lesson at the second grade of social science in Al-munawwaroh Senior High School Cilegon through implementation of snowball throwing method. This research was conducted in a collaborative and participatory in two cycles. Data collection in this research conducted with observation, questionaire and documentation. Data analysis performed was quantitative data analysis using percentage that conducted by describing the obtained quantitative data presented in the form of tables then made conclusions. Based on the research concluded that implementation of snowball throwing could increase interest and learning activity of economic lesson. The evidences were showed by improving in indicator of interest in economic lesson and learning activity. In cycle one the average score was $69,46 \%$ and in cycle two was $80,78 \%$; there were $11.32 \%$ improvement. Score of learning activity of economic lesson in cycle one was $73,62 \%$ and in cycle two was 85,65\%; the improvement of learning activity of economic lesson was 12,03\%.
\end{abstract}

Keyword: learning method, snowball throwing, interest and learning activity

\section{PENDAHULUAN}

Pendekatan Pembelajaran pada kurikulum 2013 telah beralih dari teacher center menjadi student centered yaitu siswa yang harus aktif dalam kegiatan pembelajaran, keaktifan siswa yang dimaksud yaitu siswa berpartisipasi secara aktif dalam pembelajaran, bertanya, menjawab pertanyaan, menyampaikan pendapat, dan sebagainya.

Observasi awal siswa kelas XI IPS I SMA Al-Munawwaroh, diketahui aktivitas belajar belum terjadi secara optimal. Siswa kurang memperhatikan penjelasan guru, tidak fokus saat belajar, serta metode mengajar guru yang kurang bervariasi. Siswa mengobrol dengan teman sebangku dan bermain handphone saat pembelajaran berlangsung. Hal itu mengindikasikan bahwa siswa kurang berminat terhadap mata pelajaran Ekonomi yang berakibat aktivitas belajar siswa rendah.

Minat merupakan kecenderungan untuk selalu memperhatikan dan mengingat sesuatu secara terus-menerus. 
Minat erat kaitannya dengan perasaan, terutama perasaan senang. Slameto (2013:180) mengemukakan bahwa "Minat adalah suatu rasa lebih suka dan rasa ketertarikan pada suatu hal atau aktivitas."

Minat dapat dimanifestasikan melalui partisipasi dalam suatu aktivitas. Siswa yang memiliki minat terhadap objek tertentu cenderung memberikan perhatian yang lebih besar terhadap objek tersebut. Slameto ( 2013) Sikap yang ditunjukkan siswa sebagai indikator minat belajar adalah:
a. Perhatian.
b. Rasa suka/senang.
c. Rasa terikat dengan sesuatu yang diminati.
d. Keinginan yang lebih untuk belajar.
e. Aktivitas belajar.

Dengan minat belajar yang tinggi maka akan berakibat adanya aktivitas belajar yang dilakukan oleh siswa. Dimyati (2013 : 238) menyatakan bahwa" aktivitas belajar adalah proses belajar yang berhubungan dengan bahan ajar dan dapat diamati oleh guru". Proses belajar yang dimaksud yaitu kegiatan yang dialami dan dihayati oleh siswa serta kegiatan mental mengolah bahan belajar atau pengalaman yang lain. Dengan demikian, aktivitas siswa sangat diperlukan dalam kegiatan belajar mengajar karena pada dasarnya siswa adalah subjek dalam kegiatan pembelajaran. Penerimaan materi pelajaran apabila dilakukan dengan aktivitas siswa sendiri, kesan dari kegiatan pembelajaran akan melekat kemudian dikeluarkan lagi dalam bentuk yang berbeda. siswa akan lebih aktif bertanya, mengajukan pendapat, menimbulkan diskusi dengan guru. dalam berbuat siswa dapat menjalankan perintah, melaksanakan tugas, yang diberikan oleh guru. Bila siswa menjadi partisipasi yang aktif, maka ia memiliki ilmu/pengetahuan itu dengan baik (Slameto, 2013:36).

Aktivitas Belajar ekonomi adalah kegiatan-kegiatan siswa yang menunjang keberhasilan belajar ekonomi yang merupakan interaksi antara siswa dengan guru untuk mencapai tujuan pembelajaran. Aktivitas belajar siswa dalam kegiatan pembelajaran dapat diketahui dengan adanya kemauan untuk belajar dan merespon/mencurahkan perhatian terhadap materi pelajaran selama proses pembelajaran berlangsung. Aktivitas Belajar ekonomi terdiri dari beberapa jenis antara lain: kegiatan mendengarkan, menulis, dan lisan. Menurut Paul D. Derich dalam Hamalik (2015) kegiatan belajar dibagi dalam 8 kelompok, yaitu:
a. Kegiatan-kegiatan visual
b. Kegiatan-kegiatan lisan (oral).
c. Kegiatan-kegiatan mendengarkan
d. Kegiatan-kegiatan menulis 
e. Kegiatan-kegiatan menggambar

f. Kegiatan-kegiatan metrik.

g. Kegiatan-kegiatan mental

h. Kegiatan-kegiatan emosional

Berbagai metode pembelajaran yang berorientasi pada aktivitas belajar siswa saat ini telah banyak dikemukakan. Salah satu model pembelajaran yang bisa digunakan untuk meningkatkan Minat Belajar ekonomi siswa yaitu metode Snowball Throwing. Metode ini melatih siswa untuk bekerja secara koperatif dalam pembelajaran.

Menurut Huda (2014:226) metode pembelajaran Snowball Throwing merupakan pembelajaran yang diadopsi pertama kali dari game fisik dimana segumpalan salju dilempar dengan maksud memukul orang lain. Pada konteks pembelajaran, Snowball Throwing diterapkan dengan cara melempar gumpalan kertas untuk memperoleh siswa yang akan menjawab soal dari guru. metode ini digunakan untuk memberikan konsep pemahaman materi yang sulit kepada siswa serta dapat juga digunakan untuk mengetahui sejauh mana pengetahuan dan kemampuan siswa dalam materi tersebut.

Langkah-langkah Metode Snowball Throwing menurut Suprijono (2010) adalah sebagai berikut : a. Guru menyampaikan materi yang akan disajikan.

b. Guru membentuk kelompok-kelompok acak, kemudian memanggil masingmasing ketua kelompok untuk memberikan penjelasan mengenai materi pembelajaran.

c. Ketua kelompok dipilih oleh anggota kelompok dengan penentuan suara terbanyak.

d. Masing-masing ketua kelompok kembali ke kelompoknya kemudian menjelaskan materi yang telah disampaikan guru kepada anggota kelompoknya.

e. Kemudian masing-masing siswa diberikan satu lembar kertas kerja untuk menuliskan satu pertanyaan mengenai materi yang sudah dijelaskan oleh ketua kelompok.

f. Kertas tersebut dibuat seperti bola dan dilempar dari satu siswa ke siswa yang lain selama +15 menit.

g. Setelah siswa memperoleh bola soal diberikan kesempatan untuk menjawab pertanyaan tersebut secara bergantian.

h. Evaluasi. Evaluasi dilakukan oleh guru dengan memberikan pertanyaanpertanyaan benar salah mengenai materi yang dibahas dan disajikan dalam bentuk kuis rebutan.

i. Penutup. Guru menutup pembelajaran dengan meminta siap menyimpulkan 
bersama-sama materi pembelajaran saat itu

Pada pembelajaran Snowball Throwing, siswa dibagi menjadi beberapa kelompok, setiap kelompok diwakili ketua kelompok untuk memperoleh tugas dari guru. kemudian, masing-masing siswa membuat pertanyaan di selembar kertas yang dibentuk seperti bola (kertas pertanyaan) kemudian dilempar ke siswa lain. Siswa yang mendapat lemparan kertas harus menjawab pertanyaan dalam kertas yang diperoleh.

Metode pembelajaran ini melatih siswa untuk lebih tanggap menerima pesan dari siswa lain dan menyampaikan pesan tersebut kepada teman satu kelompoknya. Melalui metode Snowball Throwing, siswa saling ketergantungan positif, setiap siswa merasa berperan, bertanggungjawab, memupuk kerja sama yang harmonis,

Dengan diterapkannya metode Snowball Throwing ini diharapkan minat belajar siswa terhadap pelajaran ekonomi semakin tinggi dan siswa menjadi aktif belajar baik secara mandiri maupun berkelompok.

\section{METODE PENELITIAN}

Penelitian dilaksanakan menggunakan penelitian tindakan kelas yang bersifat kalaboratif dan partisipasif. Prosedur penelitian terdiri dari(1) perencanaan, (2) Pelaksanaan, (3) Observasi dan (4) refleksi

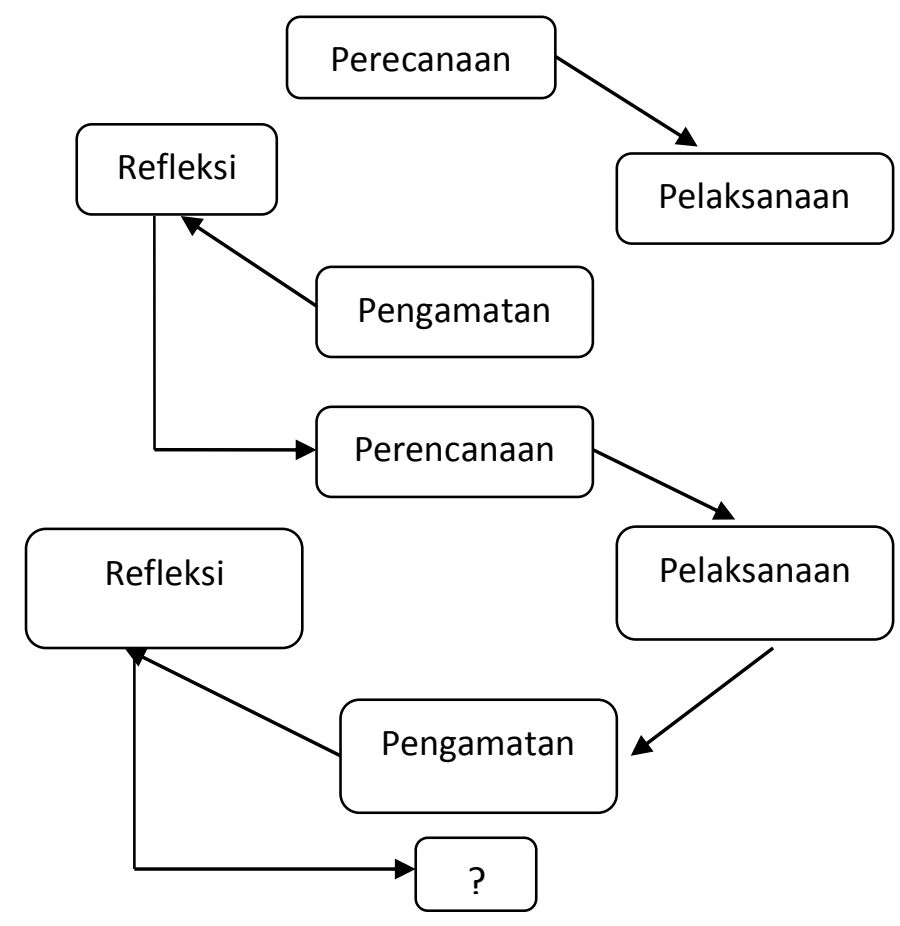

Gb.1 Alur Penelitian Tindakan Kelas Arikunto (2014:16)

Penelitian tindakan kelas dilaksanakan sampai dengan tercapainya indikator keberhasilan penelitian. Indikator keberhasilan dalam penelitian ini adalah persentase setiap indikator minat belajar dan aktivitas belajar mata pelajaran ekonomi mencapai $75 \%$ setelah mengikuti kegiatan pembelajaran menggunakan metode snowball throwing.

Data penelitian dikumpulkan menggunakan angket dan observasi. sehingga instrumen penelitian yang digunakan yakni menggunakan lembar angket dan lembar observasi. Lembar angket digunakan untuk mengukur minat 
siswa sedangkan pedoman observasi

digunakan untuk mengukur aktivitas siswa.

1. Lembar Angket

\begin{tabular}{clc}
\hline No & \multicolumn{1}{c}{$\begin{array}{c}\text { Indikator Butir } \\
\text { Pernyataan }\end{array}$} & $\begin{array}{c}\text { Nomor } \\
\text { Butir }\end{array}$ \\
\hline 1 & Perhatian & $4,5,6$ \\
2 & Rasa Suka / Senang & 7,8 \\
3 & Rasa terikat dengan & 11,12 \\
& sesuatu yang diminati & \\
4 & Keinginan yang lebih & $1,2,3$ \\
& untuk belajar & 9,10 \\
5 & Aktivitas Belajar & \\
\hline
\end{tabular}

\begin{tabular}{ll}
\hline Alternatif Jawaban & Skor \\
\hline Selalu & 4 \\
Sering & 3 \\
Kadang-kadang & 2 \\
Tidak pernah & 1 \\
\hline
\end{tabular}

2. Lembar observasi

\begin{tabular}{lll}
\hline No & Aspek Yang Diamati & Kegiatan \\
\hline 1 & Siswa membaca & Keaktifan visual \\
& materi pelajaran atau & \\
& menandai pada bagian & \\
& yang dirasa penting & \\
2 & siswa memperhatikan & Keaktifan visual \\
& penjelasan guru & \\
& ataupun siswa lain & \\
& yang sedang presentasi & \\
3 & Siswa mengemukakan & Keaktifan Lisan \\
& pertanyaan dan &
\end{tabular}

menjawab pertanyaan

pada saat

melaksanakan

permainan

4 Siswa mengemukakan Keaktifan Lisan pendapat, komentar, atau tanggapan saat diskusi

5 Siswa Keaktifan Lisan mempresentasikan hasil diskusi

6 Siswa mendengarkan Kegiatan penjelasan dari guru Mendengarkan dan diskusi dengan seksama

7 Siswa mengerjakan Kegiatan menulis tugas secara mandiri

8 Siswa mencatat Kegiatan Menulis materi, merangkum materi atau kesimpulan saat diskusi.

9 Siswa dapat bekerja Keaktifan Mental sama dengan teman satu kelompok

10 Siswa melaksanakan Keaktifan permainan melempar Matriks bola salju (Snowball throwing) dengan baik
Lembar observasi pada penelitian ini berbentuk rating scale artinya lembar observasi ini berisikan daftar semua aspek 
yang akan diobservasi yang dijabarkan ke dalam bentuk skala atau kriteria tertentu (Sanjaya, 2009: 95). Pedoman penilaian yang digunakan dalam penelitian adalah:

\begin{tabular}{cc}
\hline Kategori & Alternatif Lain \\
\hline Sangat Aktif & 4 \\
Aktif & 3 \\
Cukup Aktif & 2 \\
Tidak Aktif & 1 \\
\hline
\end{tabular}

Data hasil penelitian diolah menggunakan teknik analisis data deskriptif kuantitatif. Data yang diperoleh dari angket dan pedoman observasi berbentuk rating scale yang menunjukkan penilaian atas kemunculan kegiatan yang mencerminkan Minat dan Aktivitas Belajar mata pelajaran ekonomi. Dari hasil persentase skor akan diketahui peningkatan Minat dan Aktivitas Belajar mata pelajaran ekonomi siswa kelas XI IPS 1 SMA Al-Munawwaroh tahun ajaran 2016/2017.

\section{HASIL PENELITIAN DAN}

\section{PEMBAHASAN}

Penelitian ini dilaksanakan di Kelas XI IPS SMA Al- Munawaroh Kota Cilegon. Penelitian diawali dengan observasi kegiatan pembelajaran mata pelajaran ekonomi 25 April 2017. Hasil observasi awal menunjukkan bahwa perilaku siswa ketika mengikuti pembelajaran Kurang perhatian terhadap guru, Siswa lebih senang mengerjakan aktivitas lain seperti bermain handphone, mengobrol bersama teman sebangku, dll. Hal tersebut mengindikasikan bahwa minat dan aktivitas siswa rendah. Oleh karena itu peneliti dan guru berkalaborasi untuk meningkatkan minat dan aktivitas siswa pada mata pelajaran ekonomi

Pelaksanaan siklus 1 dimulai dari perencanaan dengan menyiapkan RPP menggunakan metode Snowball Throwing, materi pelajaran, media pelajaran, menyiapkan pedoman observasi dan angket. Tahap pelaksanaan dilakukan dengan 2 kali pertemuan sesuai dengan RPP yang dibuat dengan materi pembelajaran mengenai jurnal dan menggunakan metode pembelajaran Snowball Throwing. Setelah selesai pertemuan ke 2 siklus 1 dibagikan angket untuk mengetahui minat belajar ekonomi siswa setelah penggunaan metode Snowball Throwing.

Tabel 1 Minat Belajar Ekonomi

\begin{tabular}{lllll}
\hline $\mathrm{N}$ & Indikator & Butir & $\begin{array}{l}\text { Skor } \\
\text { Butir }\end{array}$ & $\begin{array}{l}\text { Skor } \\
\text { Indikator }\end{array}$ \\
\hline 1 & Perhatian & 4 & $63,04 \%$ & $65,21 \%$ \\
& & 5 & $57,61 \%$ & \\
& & 6 & $75,00 \%$ & \\
2 & Rasa & 7 & $72,83 \%$ & $76,09 \%$ \\
& Suka/Sena & 8 & $79,35 \%$ & \\
& ng & & & \\
& & & & \\
& & & & \\
& & & & \\
& & & & \\
\end{tabular}




\begin{tabular}{lllll}
\hline 3 Rasa & 11 & $73,91 \%$ & $76.63 \%$ \\
terikat & 12 & $79,35 \%$ & \\
dengan & & & \\
sesuatu & & & \\
yang & & & \\
$\quad$ diminati & & & \\
4 & Keinginan & 1 & $61,96 \%$ & $61,96 \%$ \\
& $\begin{array}{l}\text { yang lebih } \\
\text { untuk }\end{array}$ & 2 & $53,26 \%$ & \\
& 3 & $70,65 \%$ & \\
belajar & & & \\
Aktivitas & 9 & $63,04 \%$ & $67,39 \%$ \\
& belajar/ & 10 & $71,74 \%$ & \\
& $\begin{array}{l}\text { Partisipasi } \\
\text { di kelas }\end{array}$ & & \\
Skor Rata-Rata & & & $69,45 \%$ \\
\hline
\end{tabular}

Sumber: data yang diolah 2017

Diketahui terdapat 3 indikator yang masih di bawah indikator keberhasilan penelitian yaitu Perhatian $(65,21 \%)$, keinginan yang lebih untuk belajar (61,96\%) dan Aktivitas belajar/partisipasi di kelas (67,39\%). Sedangkan Rasa suka/senang (76,09\%) dan Rasa terikat dengan sesuatu $(76,63 \%)$ sudah mencapai indikator keberhasilan penelitian.

Pada tahap observasi dilakukan untuk mengetahui aktivitas belajar ekonomi siswa. Observasi dilakukan setiap berlangsungnya pertemuan

Tabel 2 Aktivitas Belajar Ekonomi

\section{Pertemuan 1 siklus 1}

\begin{tabular}{llll}
\hline & Indikator & Aspek yang & Skor \\
& & Diamati & \\
\hline 1 & Kegiatan & Siswa membaca & $76,81 \%$ \\
& Visual & materi pelajaran & \\
& & dan menandai & \\
& &
\end{tabular}

3 Kegiatan Siswa

Mendeng mendengarkan

arkan penjelasan dari

guru

Dan diskusi

mengemukakan

pendapat,

komentar, atau

tanggapan saat

diskusi.

Siswa

$72,46 \%$ mempresentasika $\mathrm{n}$ hasil diskusi. 


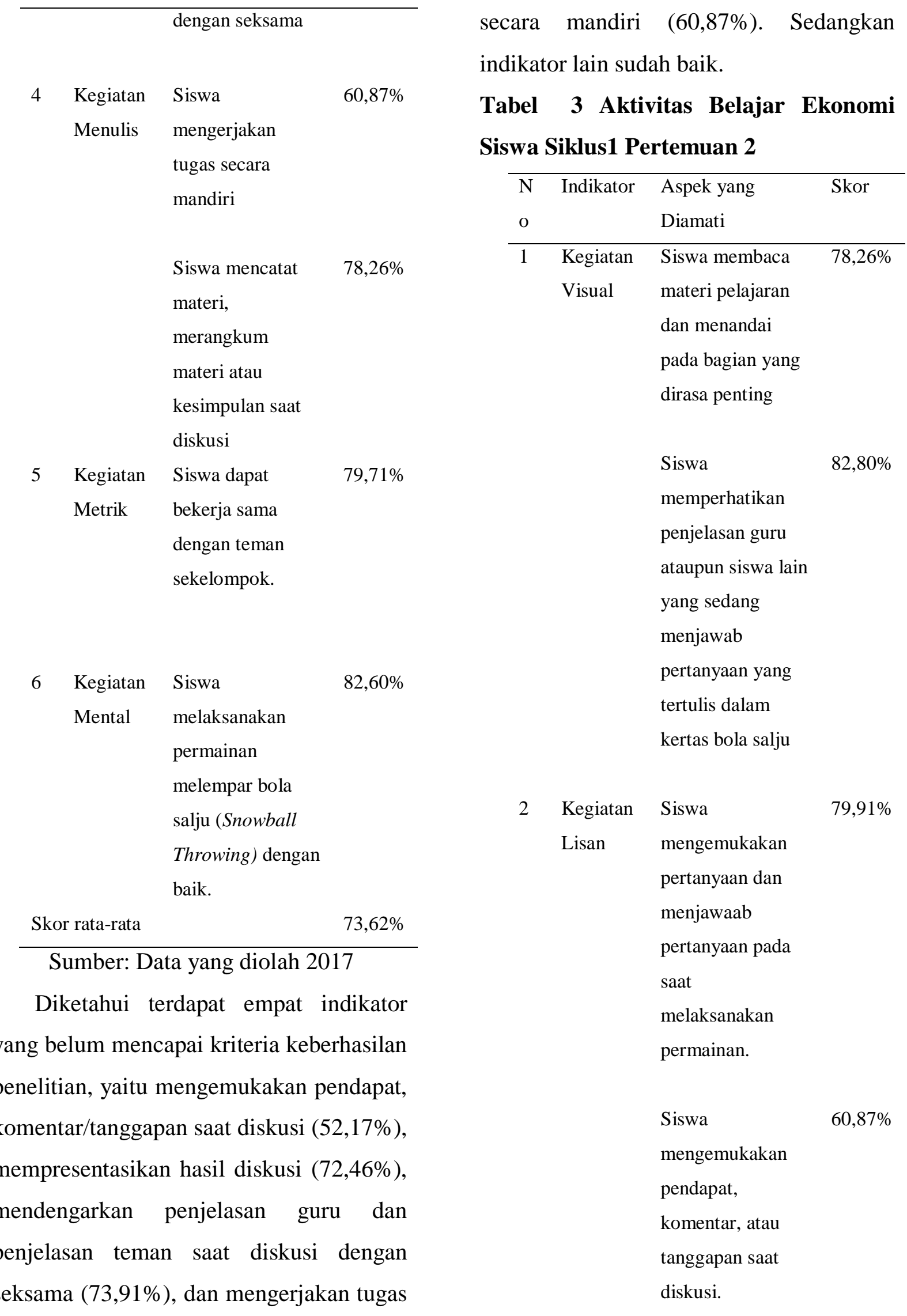


Siswa

$73,91 \%$

mempresentasika

$\mathrm{n}$ hasil diskusi.

3

$\begin{array}{ll}\text { Kegiatan } & \text { Siswa } \\ \text { Mendeng } & \text { mendengarkan } \\ \text { arkan } & \text { penjelasan dari } \\ & \text { guru }\end{array}$

Dan diskusi

dengan seksama

4 Kegiatan Siswa

Menulis

mengerjakan

tugas secara

mandiri

Siswa mencatat

materi,

merangkum

materi atau

kesimpulan saat

diskusi

5

$\begin{array}{ll}\text { Kegiatan } & \text { Siswa dapat } \\ \text { Metrik } & \text { bekerja sama } \\ & \text { dengan teman } \\ & \text { sekelompok. }\end{array}$

6 Kegiatan Siswa

Mental melaksanakan

permainan

melempar bola

salju (Snowball

Throwing) dengan

baik.

Skor rata-rata
$79 \%$

$76,81 \%$

$75,36 \%$

(7)

$81,16 \%$

$84,05 \%$

$77,21 \%$

Sumber: Data yang diolah 2017

Berdasarkan data di atas diketahui bahwa aktivitas belajar ekonomi siswa sudah membaik. Pada pertemuan pertama masih terdapat 4 indikator yang belum mencapai keberhasilan penelitian namun pada pertemuan ke 2 aktivitas belajar ekonomi siswa telah meningkat 4 indikator telah tercapai menyisakan dua indikator yang belum mencapai kriteria yaitu indikator mengemukakan pendapat, komentar, atau tanggapan saat diskusi $(60,87 \%)$ dan mempresentasikan hasil diskusi $(73,91 \%)$. Hal ini mengindikasikan bahwa ada peningkatan aktivitas belajar ekonomi siswa.

Berdasarkan pelaksanaan dan observasi kegiatan pembelajaran menggunakan metode snowball throwing diketahui bahwa minat belajar ekonomi yang terlihat dari Perhatian, keinginan yang lebih untuk belajar, dan Aktivitas belajar/partisipasi di kelas siswa masih rendah dan aktivitas belajar ekonomi kemampuan mengemukakan pendapat, komentar, atau tanggapan saat diskusi dan mempresentasikan hasil diskusi belum berlangsung dengan baik oleh karena diperlukan lanjutan siklus 2

Siklus 2 juga dilaksanakan dengan 2 kali pertemuan. Pada tahap perencanaan dilakukan seperti tahap perencanaan siklus 1 dengan perbaikan dengan pemberian motivasi untuk lebih berani 
mengemukakan pendapat dan mempresentasikan hasil diskusi. Pada tahap pelaksanaan dilakukan pengimplementasian dari RPP dengan metode Snowball Throwing. Pada akhir pertemuan 2 siklus 2 juga dibagikan angket minat belajar ekonomi siswa. Terlihat sudah terdapat peningkatan minat belajar ekonomi setelah menggunakan metode pembelajaran Snowball Throwing

Tabel 4 Minat Belajar Ekonomi

\begin{tabular}{|c|c|c|c|c|}
\hline $\begin{array}{l}\mathrm{N} \\
\mathrm{o}\end{array}$ & Indikator & Butir & $\begin{array}{l}\text { Skor } \\
\text { Butir }\end{array}$ & $\begin{array}{l}\text { Skor } \\
\text { Indikator }\end{array}$ \\
\hline 1 & Perhatian & $\begin{array}{l}4 \\
5 \\
6\end{array}$ & $\begin{array}{l}80.43 \% \\
75,00 \% \\
83,7 \%\end{array}$ & $79,71 \%$ \\
\hline 2 & $\begin{array}{l}\text { Rasa } \\
\text { Suka/Sena } \\
\text { ng }\end{array}$ & $\begin{array}{l}7 \\
8\end{array}$ & $\begin{array}{l}79,35 \% \\
84,78 \%\end{array}$ & $82,07 \%$ \\
\hline 3 & $\begin{array}{l}\text { Rasa } \\
\text { terikat } \\
\text { dengan } \\
\text { sesuatu } \\
\text { yang } \\
\text { diminati }\end{array}$ & $\begin{array}{l}11 \\
12\end{array}$ & $\begin{array}{l}78,26 \% \\
86,96 \%\end{array}$ & $82,61 \%$ \\
\hline 4 & $\begin{array}{l}\text { Keinginan } \\
\text { yang lebih } \\
\text { untuk } \\
\text { belajar }\end{array}$ & $\begin{array}{l}1 \\
2 \\
3\end{array}$ & $\begin{array}{l}78,25 \% \\
75,00 \% \\
84,76 \%\end{array}$ & $79.33 \%$ \\
\hline 5 & $\begin{array}{l}\text { Aktivitas } \\
\text { belajar/ } \\
\text { Partisipasi } \\
\text { di kelas }\end{array}$ & $\begin{array}{l}9 \\
10\end{array}$ & $\begin{array}{l}78,00 \% \\
82,61 \%\end{array}$ & $80,16 \%$ \\
\hline Skc & Rata-Rata & & & $80,78 \%$ \\
\hline
\end{tabular}

\section{Sumber: Data yang diolah 2017}

Berdasarkan analisis data angket diketahui bahwa bahwa Minat Belajar ekonomi setelah pelaksanaan siklus 2 mengalami banyak peningkatan Semua indikator telah mencapai kriteria minimal keberhasilan penelitian.

Tahap pengamatan pada siklus 2 mengenai aktivitas belajar ekonomi siswa juga mengalami peningkatan.

Tabel 5 Aktivitas Belajar Ekonomi Siswa Siklus 2 Pertemuan 1

\begin{tabular}{|c|c|c|c|}
\hline $\mathrm{N}$ & Indikator & Aspek yang & Skor \\
\hline $\mathrm{O}$ & & Diamati & \\
\hline \multirow[t]{14}{*}{1} & Kegiatan & Siswa membaca & $81,15 \%$ \\
\hline & Visual & materi pelajaran & \\
\hline & & dan menandai & \\
\hline & & pada bagian yang & \\
\hline & & dirasa penting & \\
\hline & & Siswa & $84,05 \%$ \\
\hline & & memperhatikan & \\
\hline & & penjelasan guru & \\
\hline & & ataupun siswa lain & \\
\hline & & yang sedang & \\
\hline & & menjawab & \\
\hline & & pertanyaan yang & \\
\hline & & tertulis dalam & \\
\hline & & kertas bola salju & \\
\hline \multirow[t]{9}{*}{2} & Kegiatan & Siswa & $81,15 \%$ \\
\hline & Lisan & mengemukakan & \\
\hline & & pertanyaan dan & \\
\hline & & menjawaab & \\
\hline & & pertanyaan pada & \\
\hline & & saat & \\
\hline & & melaksanakan & \\
\hline & & permainan. & \\
\hline & & Siswa & $76,81 \%$ \\
\hline
\end{tabular}




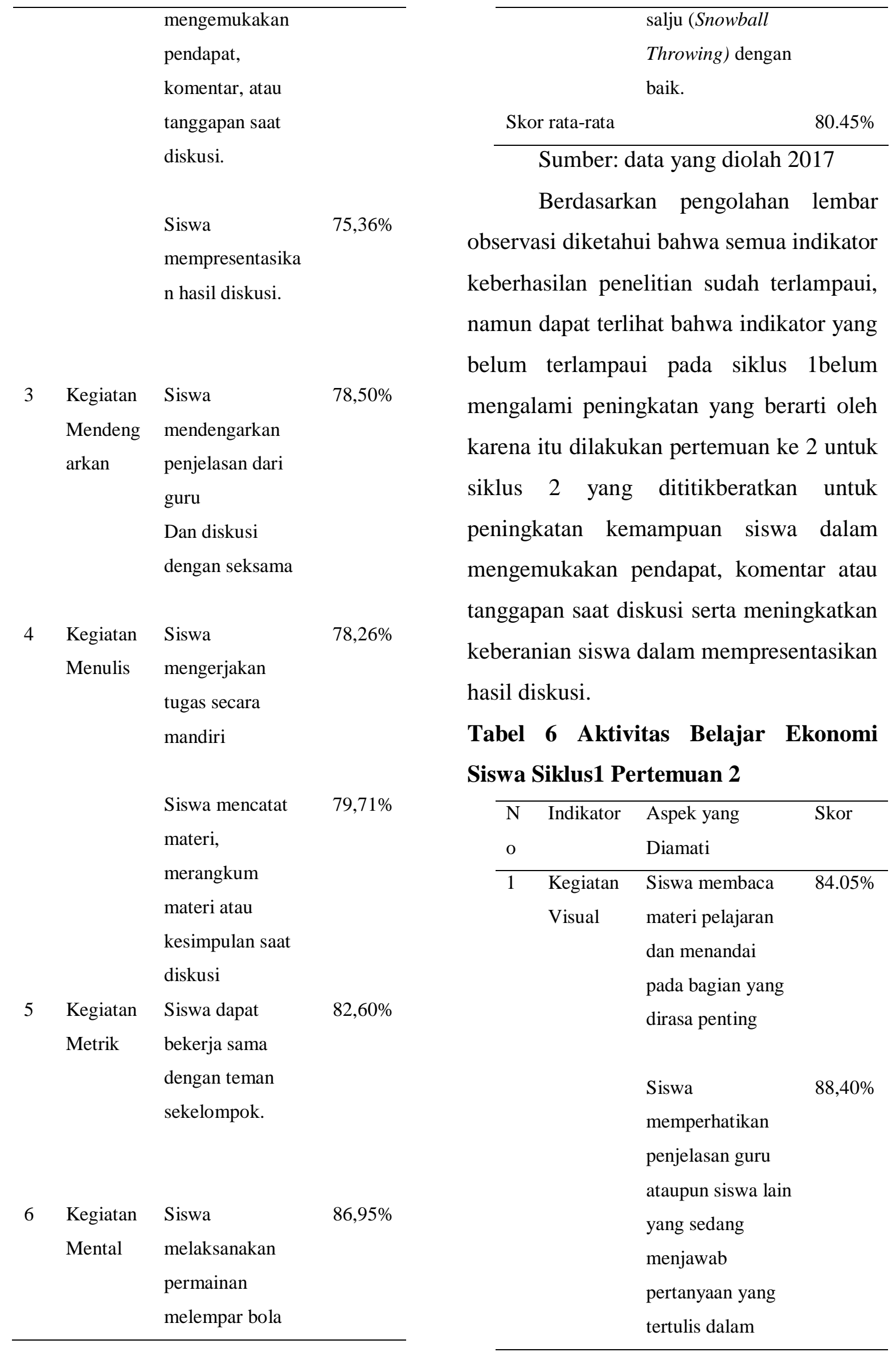




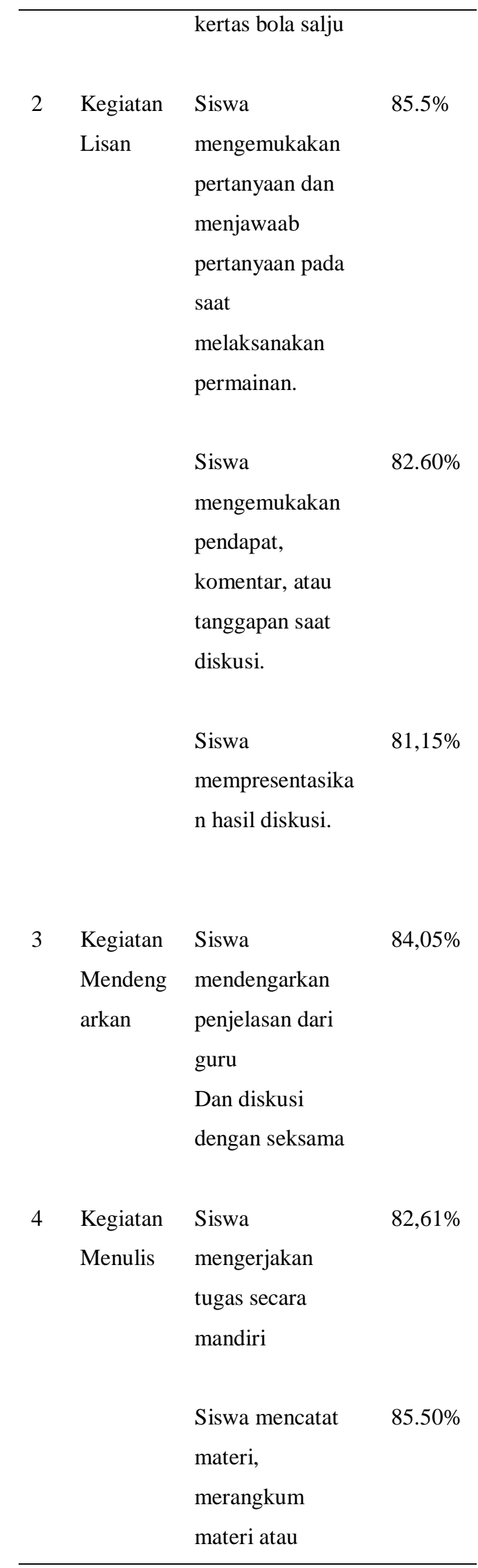

\begin{tabular}{|c|c|c|c|}
\hline \multirow[b]{2}{*}{5} & & $\begin{array}{l}\text { kesimpulan saat } \\
\text { diskusi }\end{array}$ & \multirow[b]{2}{*}{$88.40 \%$} \\
\hline & $\begin{array}{l}\text { Kegiatan } \\
\text { Metrik }\end{array}$ & $\begin{array}{l}\text { Siswa dapat } \\
\text { bekerja sama } \\
\text { dengan teman } \\
\text { sekelompok. }\end{array}$ & \\
\hline 6 & $\begin{array}{l}\text { Kegiatan } \\
\text { Mental }\end{array}$ & $\begin{array}{l}\text { Siswa } \\
\text { melaksanakan } \\
\text { permainan } \\
\text { melempar bola } \\
\text { salju (Snowball } \\
\text { Throwing) dengan } \\
\text { baik. }\end{array}$ & $94,20 \%$ \\
\hline & rata-rata & & $85,65 \%$ \\
\hline
\end{tabular}

Sumber: Data yang diolah 2017

Berdasarkan

pelaksanaan

pertemuan ke 2 siklus 2 diketahui bahwa aktivitas belajar ekonomi siswa terutama pada kemampuan mengemukakan pendapat, komentar, atau tanggapan saat diskusi telah meningkat menjadi $82,60 \%$ dan kemampuan siswa dalam mempresentasikan hasil diskusi menjadi $81,15 \%$ hal ini mengindikasikan bawa siswa telah mengalami peningkatan aktivitas belajar yang signifikan ketika pembelajaran dilakukan dengan metode snowball throwing.

Berdasarkan hasil penelitian siklus 2 pertemuan 1 dan 2, RPP siklus 2 dapat terlaksana dengan baik. Hal ini dapat dilihat dari hasil observasi bahwa semua indikator telah mencapai indikator 
keberhasilan penelitian sehingga penelitian sudah dapat dihentikan.

Berdasarkan penelitian yang telah dilaksanakan dimulai dari tahap perencanaan, tindakan, pengamatan, dan refleksi Pelaksanaan pembelajaran dengan Metode Snowball Throwing pada siklus 1 dan 2 terlihat Minat Belajar Ekonomi siswa meningkat.

Tabel 7 Minat Belajar Ekonomi

\begin{tabular}{|c|c|c|c|c|}
\hline \multirow{2}{*}{$\begin{array}{l}\mathbf{N} \\
\mathbf{0}\end{array}$} & \multirow[t]{2}{*}{ Indikator } & \multicolumn{2}{|c|}{ Skor \% } & \multirow{2}{*}{$\begin{array}{c}\text { Pening } \\
\text { katan } \\
\%\end{array}$} \\
\hline & & Siklus 1 & Siklus 2 & \\
\hline 1 & Perhatian & $65,21 \%$ & $79,71 \%$ & $14,50 \%$ \\
\hline \multirow[t]{3}{*}{2} & Rasa & $76,09 \%$ & $82,07 \%$ & $5,98 \%$ \\
\hline & Suka/Sena & & & \\
\hline & ng & & & \\
\hline \multirow[t]{6}{*}{3} & Rasa & $76.63 \%$ & $82,61 \%$ & $5.98 \%$ \\
\hline & terikat & & & \\
\hline & dengan & & & \\
\hline & sesuatu & & & \\
\hline & yang & & & \\
\hline & diminati & & & \\
\hline \multirow[t]{4}{*}{4} & Keinginan & $61,96 \%$ & $79,33 \%$ & $17,37 \%$ \\
\hline & yang lebih & & & \\
\hline & untuk & & & \\
\hline & belajar & & & \\
\hline \multirow[t]{5}{*}{5} & Aktivitas & $67,39 \%$ & $80,16 \%$ & $12.77 \%$ \\
\hline & belajar/ & & & \\
\hline & Partisipasi & & & \\
\hline & di kelas & & & \\
\hline & Rata-rata & $69,46 \%$ & $80,78 \%$ & $11,32 \%$ \\
\hline
\end{tabular}

Sumber: Data yang diolah 2017

Berdasarkan data peningkatan persentase Minat Belajar ekonomi diketahui bahwa pada siklus 2 terdapat dua indikator yang memiliki hasil terendah yaitu perhatian dan keinginan yang lebih untuk belajar

Pada indikator perhatian Pada siklus 1 siswa masih kurang tertarik untuk mempelajari ekonomi karena masih menganganggap ekonomi adalah pelajaran yang membosankan sehingga kurang memperhatikan dan kurang antusias dalam belajar. Pada siklus 2 dengan menggunakan metode snowball throwing siswa merasa pelajaran ekonomi menyenangkan. Komalasari (2014: 67), menjelaskan bahwa Metode Snowball Throwing ini menggali potensi kepemimpinan siswa dalam kelompok dan keterampilan membuat-menjawab pertanyaan yang dipadukan melalui permainan imajinatif membentuk dan melempar bola salju. Hal ini membuat suasana pembelajaran lebih menyenangkan bagi siswa. Penerapan pembelajaran ini mampu meningkatkan perhatian dan fokus ketika pembelajaran berlangsung.

indikator keinginan yang lebih untuk belajar juga memiliki nilai persentase terkecil akan tetapi memiliki peningkatan terbesar jika dibandingkan dengan siklus 1. Menurut Komalasari (2011: 67), metode Snowball Throwing merupakan pembelajaran yang dapat digunakan untuk memberikan konsep 
pemahaman materi yang sulit kepada siswa serta dapat digunakan untuk mengetahui sejauh mana pengetahuan dan kemampuan siswa dalam materi tersebut. Dengan dilaksanakannya metode Snowball Throwing ini, terbukti meningkatkan keinginan siswa untuk belajar lebih. Siswa memiliki minat untuk belajar lebih banyak materi pembelajaran ketika digunakan variasi metode pembelajaran Snowball Throwing
Penerapan metode pembelajaran Snowball Throwing selain meningkatkan minat belajar ekonomi juga mempengaruhi aktivitas belajar siswa. Siswa menjadi lebih aktif untuk mengikuti pembelajaran ekonomi dari setiap pertemuan yang dilakukan menggunakan metode snowball throwing

Tabel 8 Aktivitas Belajar Ekonomi

\begin{tabular}{|c|c|c|c|c|c|c|c|}
\hline \multirow{3}{*}{$\begin{array}{l}\mathbf{N} \\
\mathbf{0}\end{array}$} & \multirow{3}{*}{$\begin{array}{c}\text { Indikato } \\
\mathbf{r}\end{array}$} & \multirow{3}{*}{$\begin{array}{c}\text { Aspek yang } \\
\text { Diamati }\end{array}$} & \multicolumn{5}{|c|}{ Skor } \\
\hline & & & \multicolumn{2}{|c|}{ Siklus I } & \multicolumn{2}{|c|}{ Siklus 2} & \multirow[t]{2}{*}{ d-a } \\
\hline & & & 1(a) & $2(b)$ & 1(c) & $2(d)$ & \\
\hline \multirow[t]{2}{*}{1} & $\begin{array}{l}\text { Kegiatan } \\
\text { Visual }\end{array}$ & $\begin{array}{l}\text { Siswa membaca materi } \\
\text { pelajaran dan menandai } \\
\text { pada bagian yang } \\
\text { dirasa penting }\end{array}$ & $76,81 \%$ & $78,26 \%$ & $81,15 \%$ & $84,05 \%$ & $7,24 \%$ \\
\hline & & $\begin{array}{l}\text { Siswa memperhatikan } \\
\text { penjelasan guru } \\
\text { ataupun siswa lain } \\
\text { yang sedang menjawab } \\
\text { pertanyaan yang } \\
\text { tertulis dalam kertas } \\
\text { bola salju }\end{array}$ & $81,16 \%$ & $82,80 \%$ & $84,05 \%$ & $88,40 \%$ & $7,24 \%$ \\
\hline \multirow[t]{2}{*}{2} & $\begin{array}{l}\text { Kegiatan } \\
\text { Lisan }\end{array}$ & $\begin{array}{l}\text { Siswa mengemukakan } \\
\text { pertanyaan dan } \\
\text { menjawaab pertanyaan } \\
\text { pada saat } \\
\text { melaksanakan } \\
\text { permainan. }\end{array}$ & $78,26 \%$ & $79,91 \%$ & $81,15 \%$ & $85,5 \%$ & $7,24 \%$ \\
\hline & & $\begin{array}{l}\text { Siswa mengemukakan } \\
\text { pendapat, komentar, } \\
\text { atau tanggapan saat } \\
\text { diskusi. }\end{array}$ & $52,17 \%$ & $60,87 \%$ & $76,81 \%$ & $82,60 \%$ & $30,43 \%$ \\
\hline
\end{tabular}




\begin{tabular}{|c|c|c|c|c|c|c|c|}
\hline & & $\begin{array}{l}\text { Siswa } \\
\text { mempresentasikan } \\
\text { hasil diskusi. }\end{array}$ & $72,46 \%$ & $73,91 \%$ & $75,36 \%$ & $81,15 \%$ & $8,69 \%$ \\
\hline 3 & $\begin{array}{l}\text { Kegiatan } \\
\text { Mendengar } \\
\text { kan }\end{array}$ & $\begin{array}{l}\text { Siswa mendengarkan } \\
\text { penjelasan dari guru } \\
\text { Dan diskusi dengan } \\
\text { seksama }\end{array}$ & $73,91 \%$ & $76,81 \%$ & $78,50 \%$ & $84,05 \%$ & $10,14 \%$ \\
\hline 4 & $\begin{array}{l}\text { Kegiatan } \\
\text { Menulis }\end{array}$ & $\begin{array}{l}\text { Siswa mengerjakan } \\
\text { tugas secara mandiri }\end{array}$ & $60,87 \%$ & $75,36 \%$ & $78,26 \%$ & $82,61 \%$ & $21,74 \%$ \\
\hline & & $\begin{array}{l}\text { Siswa mencatat materi, } \\
\text { merangkum materi atau } \\
\text { kesimpulan saat diskusi }\end{array}$ & $78,26 \%$ & $79 \%$ & $79,71 \%$ & $85,50 \%$ & $7,24 \%$ \\
\hline 5 & $\begin{array}{l}\text { Kegiatan } \\
\text { Metrik }\end{array}$ & $\begin{array}{l}\text { Siswa dapat bekerja } \\
\text { sama dengan teman } \\
\text { sekelompok. }\end{array}$ & $79,71 \%$ & $81,16 \%$ & $82,60 \%$ & $88,40 \%$ & $8,69 \%$ \\
\hline 6 & $\begin{array}{l}\text { Kegiatan } \\
\text { Mental }\end{array}$ & $\begin{array}{l}\text { Siswa melaksanakan } \\
\text { permainan melempar } \\
\text { bola salju (Snowball } \\
\text { Throwing) dengan } \\
\text { baik. }\end{array}$ & $82,60 \%$ & $84,05 \%$ & $86,95 \%$ & $94,20 \%$ & $11,60 \%$ \\
\hline \multicolumn{2}{|c|}{ Skor rata-rata } & & $73,62 \%$ & $77,21 \%$ & $80,45 \%$ & $85,65 \%$ & \\
\hline
\end{tabular}

Sumber: Data yang diolah 2017

Dari tabel terlihat bahwa aktivitas belajar ekonomi siswa semakin meningkat. Peningkatan terbesar adalah aktivitas siswa dalam mengemukakan pendapat, komentar, atau tanggapan saat diskusi. Aktivitas ini meningkat 30, 43\%. Siswa menjadi lebih berani dalam mengkomunikasikan hasil pemikirannya. Metode snowball throwing memberikan banyak kesempatan untuk bertanya, menjawab pertanyaan dan mengemukakan pendapat. Semakin banyak kesempatan yang diberikan kepada siswa, maka siswa akan terbiasa untuk mengkomunikasikan hasil pemikirannya.

Implementasi metode snowball throwing mempengaruhi kemampuan siswa untuk mengerjakan tugas secara mandiri sebesar 21,74\%, siswa lebih terpacu untuk dapat memecahkan permasalahan sendiri. Melalui semua aktivitas selama pembelajaran seperti membaca referensi, memperhatikan guru, bertanya, menjawab pertanyaan, dan mengungkapkan pendapat bermanfaat bagi siswa untuk mengeksplor materi dan kemampuannya, sehingga siswa lebih memahami materi pelajaran dan dapat mengerjakan tugas dari guru secara mandiri

$$
\text { Berdasarkan tabel Aktivitas }
$$
Belajar ekonomi diperoleh peningkatan skor pada setiap indikator. Metode 
pembelajaran yang sesuai akan mendukung peningkatan aktivitas siswa. Suprijono (2012: 54) menyatakan bahwa "guru bertindak sebagai fasilitator, memberikan dukungan tetapi tidak mengarahkan kelompok ke arah hasil yang sudah disiapkan sebelumnya" . Hal ini sejalan Metode Snowball Throwing siswa diberi kesempatan untuk mengembangkan kemampuan, tidak hanya diam menerima materi dari guru, selain itu siswa diberi kesempatan untuk bekerja sama dengan temannya, terlibat aktif dalam pembelajaran dari awal sampai akhir, menemukan masalah, dan memecahkan masalah.

Ada beberapa upaya yang perlu dilakukan guru untuk meningkatkan Minat dan Aktivitas Belajar ekonomi, guru perlu memilih model pembelajaran yang tepat sehingga dalam proses belajar lebih menitikberatkan pada keaktifan siswa atau student centered. Pemilihan metode Snowball Throwing terbukti meningkatkan Minat dan Aktivitas Belajar ekonomi. Selama proses pembelajaran guru memberi kepercayaan dan porsi yang lebih besar kepada siswa untuk menggali kemampuan mereka dalam memahami materi pelajaran sesuai langkah-langkah pembelajaran metode ini. Dengan kepercayaan yang diberikan guru kepada siswa, tercipta suasana belajar yang mendukung peningkatan Minat dan Aktivitas Belajar ekonomi siswa. Suasana ini akan mendorong siswa untuk berinteraksi lebih efektif selama proses pembelajaran dengan sesama siswa maupun dengan guru sehingga suasana belajar menyenangkan. siswa lebih berminat terhadap pelajaran ekonomi. Selain itu, dapat meningkatkan Aktivitas Belajar ekonomi yang lebih berkualitas dan bermakna.

\section{KESIMPULAN DAN SARAN}

Berdasarkan hasil penelitian dan pembahasan dapat disimpulkan bahwa:

1) Implementasi Model Pembelajaran Kooperatif dengan Metode Snowball Throwing dapat meningkatkan Minat Belajar ekonomi pada siswa Kelas XI IPS 1 SMA Al-Munawwaroh Tahun Ajaran 2016/2017. Hal ini dibuktikan dengan terjadinya peningkatan persentase Minat Belajar ekonomi dari siklus 1 ke siklus 2. Rata-rata persentase Minat Belajar ekonomi siklus 1 menunjukkan angka 69, 46\% dan pada siklus 2 menjadi 80,78\%, implementasi metode Snowball Throwing terbukti meningkatkan minat belajar ekonomi siswa sebesar $11,32 \%$ 
2) Implementasi Metode Snowball Throwing dapat meningkatkan Aktivitas Belajar Ekonomi pada siswa Kelas XI IPS 1 SMA Al-Munawwaroh Tahun Ajaran 2016/2017. Hal ini dibuktikan dengan terjadinya peningkatan persentase Aktivitas Belajar Akuntansi dari siklus 1 ke siklus 2. Hal ini dibuktikan dengan adanya peningkatan persentase Aktivitas Belajar Akuntansi. Rata-rata persentase Aktivitas Belajar Akuntansi siklus 1 menunjukkan $73,62 \%$ dan siklus 2 sebesar $85,65 \%$, hal ini berarti terdapat peningkatan sebesar $12,03 \%$.

Berdasarkan Hasil Penelitian yang telah dilakukan, Metode Snowball Throwing terbukti mampu meningkatkan Minat dan Aktivitas Belajar ekonomi.

Adapun saran setelah dilaksanakan penelitian ini adalah:

a. Guru dapat mencoba menggunakan metode pembelajaran yang bervariasi untuk menarik dan meningkatkan Minat Belajar ekonomi siswa.

b. Guru perlu merancang pembelajaran yang mampu menumbuhkan keinginan siswa untuk belajar menjadi kegiatan mengeksplor kemampuan di dalam kelas. sehingga siswa akan terbiasa untuk aktif.

c. Guru memberikan kesempatan kepada siswa dalam pembelajaran untuk menemukan dan memecahkan masalah sendiri, sehingga siswa terbiasa untuk berpikir. Pembelajaran yang terpusat pada guru akan membuat siswa menjadi pasif.

\section{DAFTAR PUSTAKA}

Arikunto, Suharsimi. (2013). Prosedur Penelitian. Jakarta : Rineka Cipta

Dimyati\&Mudjiono. (2013). Belajar Dan Pembelajaran.Jakarta: Asdi Mahasatya

Hamalik, Oemar.(2015). KurikuluM dan Pembelajaran. Jakarta: BumiAksara

Huda,Miftahul. (2014). Model-Model Pengajaran Dan Pembelajaran. Yogyakarta: Pustaka Pelajar

Komalasari, Kokom. (2014). Pembelajaran Kontekstual Konsep dan Aplikasi. Bandung: PT RefikaAditama

Sanjaya, Wina. (2011).Strategi Pembelajaran Berorientasi standar proses Pendidikan. Jakarta: Kencana

Slameto. (2013). Belajar da nFaktorfaktor yang Mempengaruhinya. Jakarta :Rineka Cipta

Supriyono, Agus. (2010). Cooperative Learning. Surabaya: Pustaka Pelajar 